\title{
Impolite viewer responses in Arabic political TV talk shows on YouTube
}

\author{
Bahaa-eddin A. Hassan \\ Sohag University
}

The article deals with the features of impolite responses of YouTube Arab viewers of political TV talk shows. YouTube comments are written discourse of live commentary, a new genre of computer-mediated communication. Based on data from comments of Arabic viewers of political TV talk shows on YouTube, the article argues that impolite responses appear to be a common feature in Arabic comments in political talk shows on YouTube. Identity and power are reconsidered in this paper as variables that trigger impoliteness in Arabic online responses in political talk shows on YouTube. It argues that obscuring identity online incites the use of conventionalized impoliteness to exercise power on the TV presenter or the TV episode's guest. The article also shows how communication variables such as context, commentator's identity and models of communication influence the realization of impolite responses in those online interactions. The study draws on Spencer-Oatey (2007) to correlate identity, power, and impoliteness. It also utilized Culpeper's (2011) bottom-up model of impoliteness triggers.

Keywords: pragmatics, impoliteness, power, critical discourse analysis, identity, live commentary, computer-mediated communication

\section{Introduction}

\subsection{Background}

Impoliteness research has recently formed a basis in pragmatics. The phenomenon of impoliteness in online communication has become more pervasive and widespread. In traditional media, communication is a one-way process in which a sender intentionally transmits a message to a receiver (Ellis and McClintock 1990). This form is called the transmission model of communication. Although the receiver is included in the model, this role is viewed as more of an endpoint than part of the interactive process. Before the appearance of computer-mediated 
communication, the TV viewer had been defined as a recipient of the message from the sender or the TV presenter. The viewer was intimidated by the position or the authority of the TV presenter and the guest as speakers.

Online communication empowers the viewer to be a message sender by giving him/her the right to comment on the talk. The nature of online communication allows the audience to take on different discourse roles. Schlobinski and Siever $(2005,55)$ argue that users' comments are important to complement the news. This is called the interaction model of communication through which participants alternate positions as senders and receivers and generate meaning by sending messages and receiving feedback (Schramm 1997). YouTube, for example, is a website which uses an interactive model of communication: Viewers are not only recipients of the message, but also can send messages by posting comments. They have the option to exchange discourse roles in the same communicative event. The following sections discuss the phenomenon of impolite responses on YouTube.

\subsection{Research questions}

The objective of the study is to examine the impolite behavior of online commentators. The phenomenon of impoliteness in online comments became widespread. It may also reflect people's understandings of impolite behavior in public contexts. Therefore, the study aims to

1. identify impoliteness triggers in the online comments of Arabic political TV talk shows on YouTube; and

2. identify the function of impolite utterance in these online interactions; and

3. explore the impact of the communicator's identity on the realization and interpretation of impoliteness behavior.

In sum, the study provides description, analysis and rationale of impolite comments by online viewers.

\section{Literature review}

Talk shows have been rich sources for politeness and impoliteness analysis. One of the first studies on TV audience is Talk on Television: Audience Participation and Public Debate by Sonia Livingstone and Peter Lunt (1993). They deal with the critical TV viewer. Blum-Kulka (2001) also explores the history and stories of "With Meni", an Israeli talk show. The phenomenon of impoliteness in cyberspace particularly drew the attention of many scholars. Döring $(2003,270-275)$ 
discusses the aggressive behavior of users in the cyberspace. In addition, Maricic (2005) tackles the issue of 'face' in cyberspace. Similarly, Haugh (2010) deals with impoliteness in email communication. Additionally, Neurauter-Kessels (2011) discusses impolite reader responses in British online newspaper. Neurauter-Kessels (2012) discusses the personally abusive reader responses in online news media. Therefore, online reader responses became a genre which deserves to be studied. As for this genre, it is argued that talk shows are "much watched" (Squire 1997, 242), reaching an enormous number of audience. Dori-Hacohen and Shavit (2013) explore the cultural meanings of Israeli Tokbek (talk-back online commenting). Weizman and Dori-Hacohen (2017) deal with on-line commenting on opinion editorials in the Washington Post (USA) and NRG (Israel). Yet, the literature on TV talk shows and audience participation is rather limited.

Theoretically speaking, research on impoliteness cannot be detached from politeness theory. The first studies on politeness research can be traced to $\mathrm{Hu}$ (1944) and Goffman (1955) who introduced the concept of 'face'. Admittedly, Lakoff (1973), Brown and Levinson (1978/1987) and Leech (1983) are key works in politeness research. Above all, Culpeper (1996) draws the attention to impoliteness. He attempts to create a framework for impoliteness which is contrary to Brown and Levinson's (1987) theory of politeness. Specifically, Culpeper $(1996,350)$ lists all the earlier studies which dealt with hostile communication and confrontational discourse such as Craig et al. (1986), Tracy (1990), Lakoff (1989) and Penman (1990). However, Culpeper (1996) considers neither of these studies as sufficient to 'focus comprehensively' on impoliteness. Accordingly, Culpeper (1996) raised a very important question: When are we genuinely impolite? He explains that there are some circumstances in which Brown and Levinson's (1987) politeness principle fails to 'maintain each other's face. The first case is unequal power, i.e. when one participant is more powerful, $s /$ he 'has freedom to be impolite' $(1996,354)$. Culpeper (1996) proposes five super-strategies of impoliteness:

1. Bald on record impoliteness - the FTA is performed in a direct, clear, unambiguous and concise way in circumstances where face is not irrelevant or minimised. It is important to distinguish this strategy from Brown and Levinson's Bald on record. For Brown and Levinson, Bald on record is a politeness strategy in fairly specific circumstances. For example, when face concerns are suspended in an emergency, when the threat to the hearer's face is very small (e.g. "Come in" or "Do sit down"), or when the speaker is much more powerful than the hearer (e.g. "Stop complaining" said by a parent to a child). In all these cases little face is at stake, and, more importantly, it is not the intention of the speaker to attack the face of the hearer. 
2. Positive impoliteness - the use of strategies designed to damage the addressee's positive face wants.

3. Negative impoliteness - the use of strategies designed to damage the addressee's negative face wants.

4. Sarcasm or mock politeness - the FTA is performed with the use of politeness strategies that are obviously insincere, and thus remain surface realisations.

5. Withhold politeness - the absence of politeness work where it would be expected. For example, failing to thank somebody for a present may be taken as deliberate impoliteness. (Culpeper 1996,356)

Culpeper focuses on the methodology. He points out that he follows a bottomup approach which is based on empirical data. Furthermore, Culpeper's (1996) model has been utilized in a number of studies (e.g. Bousfield 2008; Cashman 2006; Lorenzo-Dus et al. 2011; Shum and Lee 2013).

Later, Culpeper (2011) points out that certain verbal expressions such as swear words and insults which are considered impolite are context-spanning. However, other expressions are context dependent. He affirms that "impoliteness is partly inherent in linguistic expression" $(2011,124)$. He also explains that while linguistics expressions can be inherently polite or impolite, speech acts cannot be. An impolite message conveyed by a conventional expression can be intensified by lexicogrammatical means such as adding modifiers or prosodic and nonverbal means.

Furthermore, Culpeper (2011) extensively explains that his model of impoliteness is based on directness. Later, Culpeper (2016) explains that

In Searle's (1975) view, the notion of directness concerns (mis)matching of syntax and speech act, and Grice is needed to guide the inferencing which bridges the gap created by a mismatch.

(Culpeper 2016, 430)

He explains that " $[\mathrm{t}]$ ransparency is lost when a speech act is not achieved through its base sentence type" (Culpeper 2016, 431). To put it differently, Culpeper (2011) divides impoliteness into two main groups: Conventionalized formulae and Implicational impoliteness. Conventionalized formulae include the following subcategories:

1. Insults

2. Pointed criticisms/complaints

3. Unpalatable questions and/or presuppositions

4. Condescensions

5. Message Enforcers

6. Dismissals

7. Silencers 


\section{Threats \\ 9. Negative Expressives}

He also sorts out three kinds of implicational impoliteness. The first one which is form-driven implicature is based on lexical cues and co-text. Examples are innuendo, snide remarks, and mocking mimicry. The second kind is conventionaldriven implicature which designates the mismatch of conventional politeness expressions with a co-text or prosodic context in which the interpretation of politeness is not acceptable. He exemplifies this kind with the word 'amazing' to imply impoliteness in an American TV show: "I think you're amazing: amazingly dreadful." (Culpeper 2011, 174).

In addition, the third kind is context-driven impoliteness which consists of the marked absence of polite behavior on the part of the speaker while it is strongly expected by the hearer. These three kinds of implicational impoliteness can be summarized as follows:

1. Form-driven: the surface form or semantic context of a behaviour is marked.

2. Convention-driven:

a. Internal: the context projected by a behaviour mismatches that projected by another part; or

b. External: the context projected by a behaviour mismatches the context of use.

3. Context-driven:

a. Unmarked behavior: an unmarked (with respect to surface form or semantic content) and unconventionalised behaviour mismatches the context; or

b. Absence of behaviour: the absence of a behaviour mismatches the context (Culpeper 2011,155-156)

Additionally, Culpeper (2011) categorizes the functions of impoliteness into four types: affective, coercive, entertaining and institutional. Affective impoliteness is "the targeted display of heightened emotion, typically anger, with the implication that the target is to blame for producing that negative emotional state" $(2011,223)$. Coercive impoliteness occurs when Speaker exercises his or her power over Hearer by using unacceptable speech patterns. The third type is entertaining impoliteness, in which a third-party audience is targeted to incite a humorous effect. The last type is institutional impoliteness in which Speaker utilizes the dominant group behind an institution. He gives the example of exploitative TV game and chat shows in which the goal is to please the viewers. 


\section{Data}

Online comments can be considered as forms of public debates where participants are expected to debate, disagree and criticize. The data which constitute online comments contain a variety of impolite responses. Communication among YouTube users is included, in addition to the responses which attack the presenter or the guest. Therefore, the type of data used in the study consists of actual instances of live text comments. Three criteria of data selection are used; (1) YouTube videos which attracted most user comments in the period from 2014 to 2018, (2) the videos which have more than 30 comments, and (3) YouTube analytics and metrics to identify the TV shows which show the high percentage of viewers (more than 100.000 viewers) who were logged in when watching the video. These criteria were applied cumulatively. They are different as the first focuses on time span, the second on number of comments and the third on the number of viewers. The data were drawn from five Arabic political TV talk shows on YouTube with their comments. The nationalities of the programs chosen are Qatari, Egyptian and Saudi. These talk shows are famous and exhibited a high percentage of viewership. The talk shows are:

1. Behind the news, $\mathrm{Al}$ Jazeera TV, Qatari

2. Every day, ON TV, Egyptian

3. Egypt to Where, CBC TV, Egyptian

4. With Turki Aldakhil, Al Arabiya TV, Saudi

5. First Edition, Dream TV, Egyptian

It is worth mentioning here that nationalities of the talk shows are not considered in the study because there is no demographics of the viewers as the audience are heterogeneous and might be anonymous. Moreover, comments in the dataset covered the following topics: national and international politics and societal issues in Egypt, Iraq and Palestine. These topics show more impolite user responses. I chose 15 TV talk shows on YouTube and examined the first 30 user comments per video. The total dataset is 450 user comments. The feature 'anonymous' is used in the analysis to describe all forms of obscuring identity whether through nicknames or pseudonyms. Even though, other non-anonymous identities might be fictional and false as well. The corpus is suitable for the study of impoliteness as anonymity seems to be an important feature of online communication. A transliteration of Arabic comments, interlinear (word-for-word) gloss, and English translations are also offered in the examples of impolite responses. 


\subsection{Live text commentary as a new genre}

One way in which a question might be approached from a critical perspective is by considering the genre that has been chosen for achieving a particular discourse goal. Live text commentary (LTC), as a genre, is a form of computer-mediated communication (cf. Jucker 2006). Apparently, computer-mediated communication (CMC), sometimes called electronic discourse, stood out in the recent decades to refer to all communications that occur via computer-mediated formats (e.g., instant messaging, email, chat rooms, online forums, live text commentaries). CMC is a new culture, a culture of netspeak and netizens. It creates a new rhetoric in the age of the internet. This new rhetoric created what is called 'audience appeal', expressing their likes and dislikes. Kjeldsen (2018) explores the relationship between rhetoric and reception. This new media rhetoric which results from new forms of communication makes it difficult to distinguish between speaker and audience.

After the appearance of LTC, relations between communicators had changed. Readers and viewers can show their instant responses to what they read and what they view. They used to be message recipients. Nowadays, they are active participants in communication. LTC is characterized by easiness and instantaneous delivery. It is acknowledged that the medium of communication influences the discourse. Online communicators are heterogeneous, i.e. they are from different cultures and different countries. Anonymity is a common feature of online communication (Herring 2001, 621). The identity of most viewers remains hidden. They use so-called pseudonyms. Therefore, online commentators are accused of unaccountability and their commentary is assumed to contain a degree of subjectivity. While the channel broadcaster has official representation, viewers have the ability to be anonymous. They are less accountable for their behavior. "The more that is known about a person, the more damaging face-threats can be" (Neurauter-Kessel 2011,196). O'Sullivian and Flanagin $(2003,71)$ outline that computer-mediated communication encourages uninhibited behavior. According to Suler (2004), this kind of anonymity gives users authority.

\subsection{Moderation}

Netiquette ethics can be an important factor in the cultural frame of communication. Online participants adhere to the rules of appropriate communicative conduct. They guarantee privacy and non-harassment of persons. In addition, moderators delete comments which are not appropriate. They might remove any content that might be considered offensive or threatening. The comments used in study are not moderated. The reason behind lack of moderation might be because 
the Arab world witnessed riots and chaos after the political uprisings in 2011. Authorities became weaker to moderate audience responses.

\section{Method of analysis}

The study has a discursive, data-driven and bottom-up approach, i.e. it is based on empirical data. The dataset of 450 user comments from the Arabic political TV talk shows on YouTube contains a variety of impolite viewer responses. First, I identified the impolite responses in the viewer's comments. For such identification, I used the framework of Culpeper's (2011) model to categorize the comments according to:

1. conventionalized impoliteness (9 subcategories)

2. implicational impoliteness

The initial analysis showed that impolite responses were recurring patterns. Then, I subcategorized conventionalized impoliteness (9 subcategories) according to Culpeper's (2011) model in addition to the implicational impoliteness. In sum, I identified 79 comments which can be classified into 10 different types of impolite responses. After having reached a categorization, I identified the strategic purpose of these impolite responses. I also took into consideration the identity of the commentator. Finally, I concluded that those types of impolite responses were used as a strategic tool to minimize the authority of the TV presenter or the guest.

\section{Results and data discussion}

This section is concerned with presenting an overview of the different subcategories in my dataset (see Table 1). They are listed by frequency.

It is worth mentioning that those types sometimes co-occur and there are some situations where a categorization is not clear-cut. The results are in line with Suler's (2004) findings of the aggressive tendencies in the cyberspace. It is noticed that conventionalized impoliteness is used more than implicational impoliteness. 74 out of 79 impoliteness occurrences are conventionalized. This can be attributed to the fact that anonymous online users do not care for face work in their interactions. The following sections are a description of each type of impoliteness with examples. 
Table 1. Overview: Types of impoliteness in 74 comments

\begin{tabular}{lc}
\hline Type of impoliteness & Frequency \\
\hline Insults & 22 \\
Pointed criticisms/complaints & 17 \\
Unpalatable questions and/or presuppositions & 7 \\
Condescensions & 4 \\
Message Enforcers & 5 \\
Dismissals & 4 \\
Silencers & 4 \\
Threats & 7 \\
Negative Expressives & 4 \\
Implicational & 5 \\
Total no. of responses & $\mathbf{7 9}$ \\
\hline
\end{tabular}

\subsection{Insults}

In this type of online interaction, the commentator calls the TV presenter or the guest bad names. In the following examples, the commentator employs conventionalized impoliteness. He uses insults or name-calling to attack the presenter. It is noticed that the identity of commentators in the following examples is obscured.

(1) Anonymous commentator:

$$
\text { أنت حمار يا حمار }
$$

?inta Huma:r ya: Huma:r

you (2.sG.M)-NOM INDF-donkey-NOM VOC INDF-donkey-NOM

'You jackass, You jackass'

(Krishan 2017, November 5)

(2) Anonymous commentator:

haða ?aj-jaHšu $\quad$ min ba:ri:s

this-DEM DEF-ass (3.SG.M)-NOM from-PREP paris-LOC

yuSadis ru?u:sana

cause. headache-CAUS-IMPF head (PL.M)-ACC-our-GEN

'This ass from Paris causes me a headache' (Krishan 2018, February 25)

Some viewers respond to the episodes with taboo words such as "bullshit", "fuck", or "son of a bitch". Notice in the following example how the commentator insults the guest. Name-calling is a common phenomenon in online interaction. Examples (3) and (4) are from the same episode; commentator 1 utters a potential face- 
threat by stating that the presenter and the episode's guest are dishonest. However, commentator 2 expresses his disapproval.

(3) Anonymous Commentator 1:

kulukum

Haramiya

كلكم حرامية ما بكم الشريف

all (PL.)-NOM-you (M.) INDEF-thieve (3.PL.M)-NOM not-NEG with.you-GEN ?al-šari:f

DEF-noble-NOM

'You are all thieves, you are not noble'

(Aldakhil 2018, January 29)

(4) Commentator 2:

layš ?al-šatim ?irtaqu: bi-? al-naqd ?al-banna:?

why-PART insult-NOM elevate-IMP with-PREP criticism-GEN constructive-GEN

'Why do you insult? You should be positive'

(Aldakhil 2018, January 29)

Results of the study show that insults constitute considerable percentage ( 22 out of 79) of the total number of impolite responses. This fact goes in accordance with the fact that the internet allows more freedom for online users.

\subsection{Pointed criticisms/complaints}

Pointed Criticism is obviously directed at the episode's guest. It is a form of destructive criticism which is meant to show that the point of view of the guest has no validity at all. Example (5) shows that the commentator uses pointed criticism to attack the TV episode's guest in Every Day Talk Show.

(5) Commentator:

?itaqi ?allah $f$ :

$$
\text { اتقى الله فى حياة الناس يا شيخ ، لا تقتل الناس بهذا الخطاب البائس }
$$

fear-IM DEF-god-ACC in-PREP life-GEN DEF-people-POSS do.not-NEG kill-IMP

?an-na:s bi-ha:ða ?al-xiTa:b ?al-ba:?is

DEF-people-ACC with-PREP this-DEM DEF-speech-GEN poor-GEN

'Be a pious Imam, do not kill people with your poor speech'

(Adeeb 2017, November 25)

Another example of pointed criticism to attack the presenter can be noticed in Example (6). 
(6) Anonymous commentator:

?al-muðişatu la: tali:qu bi-?al-muqabalati laysa:

DEF-presenter (3.SG.F.)-NOM not-NEG suit-IMPRF with.talk.show-GEN not-NEG

ladayha sumqun ka:fin lil-Hi:war

have-IMPRF depth-NOM enough-ADJ for-PREP DEF-dialogue-GEN

'The presenter is not suitable for the talk show; she has no skills for dialogue'

(Alhadidi 2015, October 9)

In the next example, instead of applauding the guest of the TV program, the commentator does not show any kind of politeness.

(7) Commentator:

muqabatun

$$
\text { fašilatun wa rutinyiatun wa }
$$

INDEF-dialogue (3.SG)-NOM poor-NOM and-CONJ routine-NOM and-CONJ

?al-?as?ilatu jahizatun

DEF-question (3.PL)-NOM ready.made-NOM

'The dialogue is poor and routine. Questions are ready-made'

(Aldakhil 2018, January 29)

The main argument is that the commentator's response is not idiosyncratic, but rather it is linked to freedom given by the internet to online users.

\subsection{Unpalatable questions and/or presuppositions}

In this form of impoliteness, the commentator challenges the TV presenter by presupposing something difficult to put up with or accept. In the following example the commentator posts an unpalatable question based on the presupposition that the one who chose the title is stupid.

(8) Anonymous commentator:

من المتخلف اللى اختار العنوان

man ?il-mutaxalif ?illi ?ixta:r ?il-sinwa:n

who-INT DEF- idiot-NOM who-REL chose-PERF DEF-title-ACC

'Who is the idiot that chose the title'

(Alhadidi 2015, April 10)

It is noted that online users sometimes use indirect speech acts to ridicule the TV presenters. In the previous example the commentator uses the form of a question to assert that the title is not acceptable. 


\subsection{Condescensions}

In this form of interaction there is an attitude of patronizing superiority or disdain. In the following example the TV presenter was telling his audience that he was to resign and leave the talk show. The commentator sarcastically responds by saying this is good.

(9) Anonymous commentator:

?afDal Ha:ja

DEF-best-COMP thing-NOM

'The best thing'

Condescension is another form of ridiculing the TV presenter. It is ironical as the response is unexpected from the commentator.

\subsection{Message enforcers}

In this type, the commentator uses an imperative to give an order or command. Given that many presenters have social media accounts, the commentator assumes that the presenter would read the comments. Notice the following example.

(10) Anonymous commentator:

$$
\text { رد علينا يا عمرو }
$$

rud Salina ya: ؟̧amr

answer-IMP us-ACC ya:-VOC amr-NOM

'answer us, you Amr'

(Adeeb 2017, December 17)

Most comments show that commentators are polarized. It has been noticed that the nastier the comments, the more polarized online users are about the content. Anderson et al. (2014) call this phenomenon "the nasty effect".

\subsection{Dismissals}

Another form of impoliteness is dismissal or rejection of the discourse in which YouTube users resort to mock the presenter or the guest. Such comments show the negative consequences of talk show comments because of a prejudice against the $\mathrm{TV}$ presenter or guest. The following example is an example of dismissal or rejection of the discussion. The commentator rejects all that is said in the episode. 
(11) Commentator:
ha:
ha:
ha:
qimatu

ههه ههه قمة المسخرة

haa-INTERJ haa-INTERJ haa-INTERJ INDEF-utmost-NOM DEF-farce-NOM

'It is a complete farce'

(Aldakhil 2018, July 3)

\subsection{Silencers}

In this type the commentator uses an imperative such as 'shut up' or any other negative expression to silence the presenter. In other words, online users exercise power on the TV presenter or the guest. They find out that online platforms have given them freedom and equal opportunities with the authorities. Notice the following example.

(12) Anonymous commentator:

أنت ممل

?anta mumil

you-NOM boring-NOM

'You are boring'

(Adeeb 2018, April 30)

Such negative user comments may sway other viewers' reactions to the content of the talk shows. Online users know that social media metrics such as the number of viewers and comments may account for the success of the program. Therefore, they behave as if they are more powerful than the TV presenter. The internet gives them more freedom to challenge authorities and criticize those who hold power.

\subsection{Threats}

Online threats are considered a form of cyber bullying. They are meant to intimidate or cause harm to the presenter. In Example (13) another commentator uses threats to attack the TV episode's guest in the Every Day Talk show. The commentator threatens the guest who is called 'Abbas', saying "Abbas must leave".

(13) Commentator:

$$
\text { الأزهر فاشل فاشل فاشل وعباس ده لازم يتشال }
$$

?al-?zhar fašil fašil fašil wa ؟abba:s

DEF-azhar-NOM loser-NOM loser-NOM loser-NOM and-CONJ abbaas-NOM

dah la:zim yiťsa:l

this-DEM must-MOD leave-INF

'Al Azhar is a loser and Abbas must leave'

(Adeeb 2017, November 25) 
After the January 25th Revolution in Egypt, online users found it easy to exercise power on authorities by raising the demonstrators' slogan of "must leave" in front of authorities to force them to resign. The commentator uses the expression "must leave" as he or she knows that the "leave' motto in Egyptian January 25th demonstrations was positive with the authorities. Therefore, this threat is direct and context-dependent as it works in Egypt. It has been also noticed that the percentage of threats as a type of impolite responses in the results of the study is relatively small ( 7 out of 79 responses).

\subsection{Negative expressives}

In the next example the commentator is attacking the presenter in a scornful or contemptuous manner. Especially the use of the adjective 'hypocrite' underlines the commentator's wish to express indifference and skepticism towards the presenter. It is an example of a negative expressive utterance which triggers conventionalized impoliteness. In Example (14) the identity of the commentator is known. It has been noticed that when the identity is visible, YouTube users do not tend to use very impolite comments such as name-calling or insults. They use less impolite responses such as negative expressions and pointed criticism.

(14) Commentator:

عمرو أديب والمدام لميس الحديدى بقوا الآن من الإعلاميين المنافقين ؟amru ?adi:b wa ?al-mada:m lami:s ?al-Hadidibaqu amr.adeeb-NOM and-CONJ madam.lamis.alhadidi-NOM became-PERF ?al-?a:n min ?al-?isla:myi:n ?al-munafiqi:n nOW-PREP from-PREP DEF-journalist (3.PL.M)-GEN hypocrite (3.PL.M)-GEN 'Amr Adeeb and Madam Lamis Alhadidi now belong to those hypocrite journalists'

(Adeeb 2017, December 19)

In the previous example, the word 'hypocrite' is not a direct insult; the commentator uses the euphemistic expression 'now belong to those hypocrite journalists.' He does not say 'you are hypocrite.

\subsection{Implicational impoliteness}

All these above mentioned forms of impoliteness are conventionalized or direct. The examples in this section rely on some kind of inference which is relative to Gricean cooperativeness (cf. 1975). Inference needs to be undertaken for the impolite implication to be drawn. The following example could be interpreted as implicational impoliteness. It is a sample of convention-driven impoliteness in which there is mismatch of conventional politeness expressions with a co-text or 
prosodic context in which the interpretation of politeness is not expected. Incongruity arises because of the clash of expectations; the clash results from mixing two opposite linguistic features - both conventionally polite and impolite. The first part 'do a favor' is conventionalized politeness (by mitigating the presenter's negative face). However, the second part of the comment attacks the presenter's positive face by using the conventionalized taboo word 'piss off'.

(15) Anonymous commentator:

اعمل معروف غور

?ismil ma؟ru:f fu:r

Do-IMP INDEF-favor-NOM piss.off-IMP

'Do a favor - piss off'

(Adeeb 2018, April 30)

The next example is a sample of context-driven impoliteness which denotes the absence of polite behavior.

(16) Anonymous commentator:

حيدورى كيوت

Hayduri: qiyu:ti:

haider-NOM cute-NOM

'Sweet cute Haider'

(Aldakhil 2018, January 29)

In Example (16), the commentator flouts the Maxim of Manner. He uses sarcasm or mock politeness. He utters a potential face-threat by labeling Mr. Haider Al Abadi, an Iraqi politician as 'Cute sweet Haider'. The next example is form-driven impoliteness. It includes innuendo; it is the surface form (semantic content) which is marked, however, the target concerned must understand the semantic content otherwise the result would be the opposite meaning. In the following example the commentator is ridiculing the presenter's high salary.

(17) Anonymous commentator:

مسكين مرتباتكم قليلة

maski:n muratabatkum qali:la

poor-NOM your-GEN salaries-NOM low-NOM

'Poor! Your salaries are low'

(Adeeb 2018, April 30)

On the surface the commentator uses positive politeness in conveying sympathy, however, the intended meaning is to ridicule those powerful people. Ross $(1998,59)$ shows that powerful groups can be the butt of humor. He explained that "the butt of humour is not always in an inferior position". Much humor is an attack on people in superior positions of power and influence. 


\section{Functions of YouTube impolite responses}

As explained above, there are four functions of impoliteness. First, some viewers use impoliteness to arouse pity through vulnerability or sadness. Notice the following affective function of impoliteness in Example (18). In responding to a YouTube video episode, the commentator directly addresses the presenter to show anger. He feels pity that they are unable to reject Trump's declaration of Jerusalem as the capital of Israel. The commentator does not target the speaker. However, he expresses his emotional state.

(18) Commentator:

\section{ya:lal}

what-PART DEF-shame-GEN VOC arab-NOM

'What a shame on you, Arab people'

(Al Muslimani 2017, December 16)

In Example (19), the commentator turns to attack the program's guest. S/he utters a potential face-threat by implicating that the program's guest is old and mentally sick. This form of impoliteness is meant to exercise power on the guest. The function of this utterance is coercive.

(19) Anonymous commentator:

$$
\text { انت لسى فيك روح ياجدو في مصحه نفسيه لي القومجين امثالك }
$$

?inta lissah fi:k ru:H ya: jiddu:

you-NOM still-ADV inside-PREP you-GEN spirit-NOM vOC grandfather-NOM

fi: maSaHHa nafsiyah lil qawmyi:n ?am0alak

there-LOC psychiatric.hospital-NOM for-PREP nationalist-GEN like.you-NOM

'You are still alive, grandfather. You, such a nationalist, go to a psychiatrist'

(Alhadidi 2015, October 9)

It has been noticed that the Arabic language used is full of spelling and grammar mistakes. In the following example, the commentator does not only attack the presenter or the guest, but s/he also targets a third-party audience to incite a humorous effect. The commentator creates the innuendo of the presenter's scalp hair. He hinted that the TV presenter was bald because he drank desalinated water. The function is an entertaining impoliteness. 
(20) Anonymous commentator:

$$
\text { ه8ه8ه تحلية مياه المجاري دي للشرب ولا للطبخ اشرب ياعمرو أديب منها لحد ما شعرك يقع }
$$

hahaha taHliyat miyah ?al-maja:ri di: lil

haa-INTERJ desalination-NOM sewage.water-GEN this-DEM for-PREP

šurb walla lil Tabx ?išrab ya: amr ?adi:b

drinking-GEN or-CONJ cooking-GEN Drink-IMP voC-amr.adeeb-NOM

laHad ma ̌̌ąr ra?sak yuqas

till-PREP scalp.hair (2.)-NOM fall-IMPERF

'Ha ha ha sewage water desalination is for drinking or cooking? Drink, Amr

Adeeb, till you lose your scalp hair'

(Adeeb 2017 December 17)

\section{Participants' identity}

The identity of commentators is a discursive construct in online interaction. Therefore, TV talk show viewers and speakers are not equal in terms of identity declaration. Culpeper $(1996,354)$ refers to the question of unequal power; i.e. when one participant is more powerful, s/he 'has freedom to be impolite' $(1996,354)$. It has been noticed that most of the online comments are politicized. Bryant $(1998,79)$ states that "the role of unequal power relations in constituting a politicized environment is a central theme". Therefore, YouTube users experience an exchange of power relations.

Spencer-Oatey (2007) tackles the question of identity and face. She notices that there are 3 functions of identity:

- Identity helps to provide people with a sense of belonging (through their relational and collective self-aspects) and with a sense of distinctiveness (through their individual self-aspects).

- Identity helps people 'locate' themselves in their social worlds. By helping to define where they belong and where they do not belong in relation to others, it helps to anchor them in their social worlds, giving them a sense of 'place'.

- The many facets of identity help provide people with self-respect and selfesteem. People's positive evaluations of their own self-aspects help build their self-esteem. $(2007,642)$

In virtual communication, participants reformulate relational practices of real life. Spencer-Oatey's (2006) definition of relational practice is "the relationship between the participants (e.g. distance-closeness, equality - inequality, perceptions of role rights and obligations), and the ways in which this relationship is managed or negotiated" (Spencer-Oatey 2007,647). Relational mismanagement takes place between interlocutors in these online comments. It seems obvious from 
the previous examples that some YouTube viewers tend to destroy the image of the presenter by posting impolite responses.

\section{Impoliteness in live commentary as a strategic tool}

Power relations are both negotiated and performed in live text commentary. Here we come to the function of online impolite responses in political discourse. The concept of function is central to discourse analysis. It refers to an action, or to what it is that audience is doing in and with their comments. Are online impolite comments strategic tools? While impoliteness in online interaction is described as hostile participation, it can be interpreted as a strategic tool which users utilize to exercise power on the TV presenter or on the guest. This has been described by Suler (2004) as "minimizing authority".

People are reluctant to say what they really think as they stand before an authority figure. A fear of disapproval and punishment from on high dampens the spirit. But online, in what feels more like a peer relationship - with the appearances of 'authority' minimized - people are much more willing to speak out or misbehave.

(2004,324)

Bousfield (2008) also points out the same justification.

Linguistic impoliteness is (an attempt) to exercise power over one's interlocutors while simultaneously ensuring that one's interlocutors are (overly) offended in the process.

(2008, 141-142)

Many studies mention impoliteness as a strategic goal (cf. Kienpointner 1997 and Levorato 2009). Kienpointner $(1997,271)$ argues that impoliteness is "a sign of power, and may therefore become a key element in the overall argumentative strategy". It has been noticed that commentators exercise power when they discursively challenge the status and power of the presenter or the guest. The speakers' power and status are challenged by claiming that they do not meet the expectations of the viewers. Speakers consider viewers' attacks as face-threats. In fact, 'face' is mutually constructed between speakers and viewers. YouTube allows users to talk back to comment on the speakers.

The phenomenon of impoliteness is not only common to YouTube comments but is noticed in newspaper comments. Results are in line with what researchers have found as a feature of CMC: the aggressive behavior of users in the cyberspace (cf. Döring 2003; O'Sullivan and Flanigan 2003; Neurauter-Kessels 2011). What can be different in the use of impoliteness in the comments of Arabic TV talk shows is that the Arab region witnessed political uprisings and protest movements 
in 2011. Authorities in these countries became weaker. Moderation and censorship were absent for some years. Comments show that there was polarization in the Arab countries after 2011.

TV talk shows viewers use different argument strategies to exercise power on the presenter or the guest. One can reflect on Paul Graham's hierarchy of disagreement. He proposes that new communication models such as computer-mediated communication "changed the way we communicate" (Graham 2008). He categorizes argumentative strategies into 7 subcategories; Name-calling, Ad Hominem, Responding to Tone, Contradiction, Counterargument, Refutation and Refuting the Central Point. Name-calling constitutes the base of his hierarchy of disagreement; i.e. online communicators show more disagreement than agreement. In Namecalling and Ad Hominem users attack the personality or the authority of the speaker without addressing the substance of the argument. The results of this study are in line with Graham's results as Name-calling has the highest frequency in the above table of impolite responses.

\section{Conclusion}

Talk is action and action is communicative (Austin 1962). It is significant to analyze political discourse in Arabic talk shows. However, other forms of discourse may also be significant, one is live written commentary. The present study proves that impolite responses are used in Arabic political TV shows in YouTube. The study argues that many viewers in the selected episodes posted on YouTube do not interact with the content of the episode. This phenomenon of impolite responses can be seen as a feature of computer-mediated communication; CMC-users practice more freedom to the extent that they devaluate TV presenters or guests. The study analyzes a sample of comments in Arabic Political TV talk shows episodes on YouTube. One of the findings is that the online impolite responses can be interpreted as a powerful tool of aggravating other's authority. The study shows that instead of debating, criticizing and disagreeing on topics, commentators respond impolitely to the presenter or the guest. The study argues that impolite responses are meant to question the TV presenter's or TV episode's guest's authority and credibility. The study advocates developing the rhetoric of reception. Instead of deleting impolite responses, the rhetoric of reception should include critical responses by the online audience. If Arabic TV talk shows provide some sort of public political debate, the online audience should post critical responses. They must possess and exercise the skills of critical response. They must respond critically and politely. Critical responses mean reasonable comments whether they support or oppose the central point of discussion in the talk show. 


\section{Data}

Adeeb, Amr. [ON TV]. (2018, April 30). Every day. [Video file]. Retrieved from https://www .YouTube.com/watch? $\mathrm{v}=$ darCZCdkXmE

Adeeb, Amr. [ON TV]. (2017, December 19). Every day. [Video file]. Retrieved from https:// www.YouTube.com/watch? $\mathrm{v}=2$ VsoKFSkIMw

Adeeb, Amr. [ON TV]. (2017, December 17). Every day. [Video file]. Retrieved from https:// www.YouTube.com/watch?v=ByoE4wBLh $33 \mathrm{U}$

Adeeb, Amr. [ON TV]. (2017, November 25). Every day. [Video file]. Retrieved from https:// www.YouTube.com/watch?v=RoiEzKL89G4

Aldakhil, Turki. [Al Arabiya TV]. (2018, March 7). With Turki Aldakhil. [Video file]. Retrieved from https://www.YouTube.com/watch? $\mathrm{v}=\mathrm{mF} 4 \mathrm{SLos} \_\mathrm{eWo}$

Aldakhil, Turki. [Al Arabiya TV]. (2018, March 5). With Turki Aldakhil. [Video file]. Retrieved from https://www.YouTube.com/watch?v=HNEKEuoV_Ug

Aldakhil, Turki. [Al Arabiya TV]. (2017, April 23). With Turki Aldakhil. [Video file]. Retrieved from https://www.YouTube.com/watch?v=7Ji7ih8mRPg

Aldakhil, Turki. [Al Arabiya TV]. (2018, January 29). With Turki Aldakhil. [Video file]. Retrieved from https://www.YouTube.com/watch?v=TyCRhzrEWG4

Alhadidi, Lamis. [CBC TV]. (2015, October 9). Egypt to Where. [Video file]. Retrieved from https://www.YouTube.com/watch?v=M4Rt_6_XzNs

Al Muslimani, Ahmad. [Dream TV]. (2017, December 16). First Edition. [Video file]. Retrieved from https://www.YouTube.com/watch?v=BHiXGe2sRbw

Al Muslimani, Ahmad. [Dream TV]. (2018, June 23). First Edition. [Video file]. Retrieved from https://www.YouTube.com/watch?v=1Q2T7acii-Q

Al Muslimani, Ahmad. [Dream TV]. (2016, December 13). First Edition. [Video file]. Retrieved from https://www.YouTube.com/watch? $\mathrm{v}=7 \mathrm{dSckheoeHI}$

Krishan, Muhammad. [Al Jazeera TV]. (2018, February 25). Behind the news. [Video file]. Retrieved from https:/www.YouTube.com/watch?v=7pHdNqpg $5 \mathrm{Fc}$

Krishan, Muhammad. [Al Jazeera TV]. (2017, November 7). Behind the news. [Video file]. Retrieved from https://www.YouTube.com/watch?v=dvHmisr46ho

Krishan, Muhammad. [Al Jazeera TV]. (2018, June 11). Behind the news. [Video file]. Retrieved from https://www.YouTube.com/watch?v=AKZeN78EJ_g

\section{References}

Anderson, Ashley, Dominique Bossard, Dietram Scheufele, Michael Xenos, and Peter Ladwig. 2014. "The 'Nasty Effect': Online Incivility and Risk Perceptions of Emerging

Technologies” Journal of Computer-Mediated Communication 19: 373-387. https://doi.org/10.1111/jcc4.12009

Austin, John L. 1962. How to Do Things with Words. Cambridge, Massachusetts: Harvard University Press.

Blum-Kulka, Shoshana. 2001. "The Many Faces of With Meni: The History and Stories of One Israeli Talk Show." In Television Talk shows. Discourse, Performance, Spectacle, ed. by Andrew Tolson, 89-115. Mahwah, NJ: Erlbaum. 
Bousfield, Derek. 2008. Impoliteness in Interaction. Philadelphia and Amsterdam: John Benjamins. https://doi.org/10.1075/pbns.167

Brown, Penelope, and Stephen Levinson. 1978/1987. Politeness. Cambridge: Cambridge University Press.

Bryant, Raymond L. 1998. "Power, Knowledge and Political Ecology in the Third World: A

Review”. Progress in Physical Geography 22 (1): 79-94.

https://doi.org/10.1177/030913339802200104

Cashman, Holly. 2006. “Impoliteness in Children's Interactions in a Spanish/English Bilingual Community of Practice." Journal of Politeness Research, Language, Behaviour, Culture 2

(2): $217-246$.

Craig, Robert T., Karen Tracy, and Frances Spisak. 1986. "The Discourse of Requests:

Assessment of a Politeness Approach”, Human Communication Research, 12, (4), 437-468. https://doi.org/10.1111/j.1468-2958.1986.tbooo87.x

Culpeper, Jonathan. 1996. "Towards an Anatomy of Impoliteness". Journal of Pragmatics 25 (3): 349-367. https://doi.org/10.1016/0378-2166(95)00014-3

Culpeper, Jonathan, Derek Bousfield, and Anne Wichmann. 2003. "Impoliteness Revisited:

With Special Reference to Dynamic and Prosodic Aspects". Journal of Pragmatics 35

(10/11): 1545-1579. https://doi.org/10.1016/So378-2166(02)o0118-2

Culpeper, Jonathan. 2011. Impoliteness: Using Language to Cause Offence. Cambridge:

Cambridge University Press. https://doi.org/10.1017/CBO9780511975752

Culpeper, Jonathan. 2016. "Impoliteness Strategies". In Interdisciplinary Studies in Pragmatics, Culture and Society, ed. by Alessandro Capone and Jacob L. Mey, 421-445. Basel:

Springer international. https://doi.org/10.1007/978-3-319-12616-6_16

Dori-Hacohen, Gonen, and Nimrod Shavit. 2013. "The Cultural Meanings of Israeli Tokbek (Talk-Back Online Commenting) and their Relevance to the Online Democratic Public Sphere." Int. J. Electronic Governance 6 (4): 361-379.

https://doi.org/10.1504/JJEG.2013.060649

Döring, Nicola. 2003. Sozialpsychologie des Internet. Die Bedeutung des Internet für Kommunikationsprozesse, Identitäten, soziale Beziehungen und Gruppen. [Social psychology of the internet: the importance of the internet for communication processes, identity, social relations and groups] 2nd edn. Göttingen: Hogrefe.

Ellis, R., and Ann Mc Clintock. 1990. You Take My Meaning: Theory into Practice in Human Communication. London: Edward Arnold.

Grice, H. Paul. 1975. "Logic and Conversation". In Syntax and Semantics, Vol. 3, Speech Acts, ed. by Peter Cole and Jerry L. Morgan, 41-58. New York: Academic Press.

Haugh, Michael. 2010. "When is an Email Really Offensive? Argumentativity and Variability in Evaluations of Impoliteness". Journal of Politeness Research 6: 7-31. https://doi.org/10.1515/jplr.2010.002

Herring, Susan C. 2001. "Computer-mediated Discourse”. In The Handbook of Discourse Analysis, ed. by Deborah Tannen, Deborah Schiffrin and Heidi Hamilton, 612-634. Oxford: Blackwell.

Hu, Hsien Chin. 1944. “The Chinese Concept of 'Face”. American Anthropologist 46 (1): 45-64. https://doi.org/10.1525/aa.1944.46.1.02a00040

Goffman, Erving. 1955. "On Facework: An Analysis of Ritual Elements in Social Interaction”. Psychiatry: Journal of Interpersonal Relations 18 (3): 213-231.

https://doi.org/10.1080/00332747.1955.11023008 
Graham, Paul. 2008. “How to Disagree” http://www.paulgraham.com/disagree.html (last retrieved 16/4/2018).

Jucker, Andreas H. 2006. "Live text commentaries. Read about it while it happens". In Androutsopoulos, Jannis K., Jens Runkehl, Peter Schlobinski und Torsten Siever (eds.) Neuere Entwicklungen in der linguistischen Internetforschung. Zweites internationals Symposium zur gegenwärtigen linguistischen Forschung über computervermittelte Kommunikation. Universität Hannover. 4.-6. Oktober 2004.

Kienpointner, Manfred. 1997. "Varieties of Rudeness: Types and Functions of Impolite Utterances”. Functions of Language 4 (2): 251-287. https://doi.org/10.1075/fol.4.2.05kie Kjeldsen, Jens. 2018. Rhetorical Audience Studies and Reception of Rhetoric. Palgrave: Palgrave Macmillan. https://doi.org/10.1007/978-3-319-61618-6

Lakoff, Robin. 1973. “The Logic of Politeness or, Minding your P's and Q's”. In Papers from the 9th Regional Meeting of the Chicago Linguistic Society, ed. by C. Corum,

T. Cedric Smith-Stark, and A. Weiser, 292-305. Chicago: Chicago Linguistic Society.

Lakoff, Robin. 1989. "The Limits of Politeness: Therapeutic and Courtroom Discourse”.

Multilingua 8 (2-3): 101-129. https://doi.org/10.1515/mult.1989.8.2-3.101

Leech, Geoffrey. 1983. Principles of Pragmatics. London: Longman.

Levorato, Alessandra. 2009. "From You, my Lord, Professions Are but Words - They Are so Much Bait for Fools to Catch at", Impoliteness strategies in the 1797-180o Act of Union pamphlet debate. In Early modern English news discourse: Newspapers, pamphlets and scientific news discourse, ed. by Andreas H. Jucker, 159-185. Amsterdam: John Benjamins.

Livingstone, Sonia, and Peter Lunt. 1993. Talk on Television: Audience Participation and Public Debate. London: Routledge. https://doi.org/10.4324/9780203310243

Lorenzo-Dus, Nuria, Pilar Garces-Conejos Blitvich, and Patricia Bou-Franch. 2011. "Online Polylogues and impoliteness: The Case of Postings Sent in Response to the Obama Reggaeton You Tube Video". Journal of Pragmatics 43: 2578-2593. https://doi.org/10.1016/j.pragma.2011.03.005

Maricic, Ibolya. 2005. Face in Cyberspace: Facework, (Im)politeness and Conflict in English Discussion Groups (PhD thesis). Vaxjo: Vaxjo University Press.

Neurauter-Kessels, Manuela. 2011. "Im/polite Reader Responses on British Online News Sites". Journal of Politeness Research 7(2): 187-214. https://doi.org/10.1515/jplr.2011.010

Neurauter-Kessels, Manuela. 2012. Impoliteness in Cyberspace: Personally Abusive Reader Responses in Online News Media (PhD thesis). Department of English, University of Zurich.

O’Sullivan, Patrick, and Andrew Flanigan. 2003. "Reconceptualizing 'Flaming' and other Problematic Communication”. New Media and Society 5: 67-93. https://doi.org/10.1177/1461444803005001908

Penman, Robyn. 1990. "Facework and Politeness: Multiple Goals in Courtroom Discourse". Journal of Language and Social Psychology 9: 15-38. https://doi.org/10.1177/0261927X9091002 Ross, Alison. 1998. The Language of Humor. London: Routledge.

Schlobinski, Peter, and Thorsten Siever. 2005. "Sprachliche und textuelle Aspekte in deutschen Weblogs" [Linguistic and textual aspects in German Weblogs]. In Sprachliche und textuelle Merkmale in Weblogs [Linguistic and textual features in weblogs]: Ein internationales Projekt, ed. by Peter Schlobinski and Thorsten Siever. (Networx 46), 5285. http://www.mediensprache.net/networx/networx-46.pdf

Schramm, Wilbur. 1997. The Beginnings of Communication Study in America: A Personal Memoir. Thousand Oaks, CA: SAGE Publications, Inc. 
Searle, John. 1975. “Indirect Speech Acts”. In Syntax and Semantics, ed. by Cole, Peter and Jerry L. Morgan, Vol. 3: Speech Act, 59-82. New York: Academic Press.

Shum, Winnie, and Cynthia Lee. 2013. "( $\mathrm{Im})$ politeness and Disagreement in Two Hong Kong Internet Discussion Forums". Journal of Pragmatics 50 (1): 52-83. https://doi.org/10.1016/j.pragma.2013.01.010

Spencer-Oatey, Helen. 2007. "Theories of Identity and the Analysis of Face”. Journal of Pragmatics 39 (4): 639-656. https://doi.org/10.1016/j.pragma.2006.12.004

Squire, Corinne. 1997. "Who's White? Television Talk Shows and Representations of Whiteness". In Off White: Readings on Race, Power, and Society, ed. by Michelle Fine, Lois Weis, Linda C. Powell and L. Mun Wong, 242-250. New York, NY: Routledge.

Suler, John. 2004. “The Psychology of Cyberspace”. http://www-usr.rider.edu/ suler/psycyber /disinhibit.html (accessed 6 December 2008).

Tracy, Karen. 1990. “The Many Faces of Facework”. In Handbook of Language and Social Psychology, ed. by Howard Giles and W. Peter Robinson, 209-226. Chichester: John Wiley and Sons.

Weizman, Elda, and Gonen Dori-Hacohen. 2017. "On-line Commenting on Opinion Editorials: A Cross-cultural Examination of Face Work in the Washington Post (USA) and NRG (Israel)". Discourse Context and Media, 19: 39-48.

https://doi.org/10.1016/j.dcm.2017.02.001

\section{Appendix. Transliteration conventions}

In transcribing the examples, the study uses the following symbols:

\section{Consonants}

Arabic symbol

ب /b/ voiced bilabial stop

ت / / / voiceless dental stop

ث $\quad / \theta /$ voiceless inter-dental fricative

ج / / j/ voiced alveo-palatal affricate

$\tau / \mathrm{H} /$ voiceless pharyngeal fricative

خ /x/ voiceless uvular fricative

د $/ \mathrm{d} /$ voiced dental stop

j $\quad /$ / voiced inter-dental fricative

, /r/ alveolar trill

j $\quad / z /$ voiced dento-alveolar fricative

/s/ voiceless dento-alveolar fricative

ش / / / / voiceless alveo-palatal fricative

ص /S/ voiceless dento-alveolar emphatic fricative

ض /D/ voiced dento-alveolar emphatic stop

b /T/ voiceless dento-alveolar emphatic stop

b /Z/ voiced dental emphatic fricative

$\varepsilon \quad / ؟ /$ voiced pharyngeal fricative 
$\dot{\varepsilon} / \mathrm{\gamma} /$ voiced uvular fricative

ف / / / / / voiceless labio-dental fricative

ق /q/ voiceless uvular stop

s) $/ \mathrm{k} /$ voiceless velar stop

」 / / / voiced alveolar lateral

م $\quad / \mathrm{m} /$ voiced bilabial nasal

ن / / / voiced alveolar nasal

- /h/ voiceless glottal fricative

s / / / voiced glottal stop

๑ /W/ voiced bilabial approximant

$\checkmark$ / /y/ voiced palatal approximant

Vowels

/i/ high front /ii/ its long counterpart

/u/ high back /uu/ its long counterpart

/a/ low central /aa/ its long counterpart

\section{Address for correspondence}

Bahaa-eddin A. Hassan

Assistant Prof.

Sohag University

Sohag

B.O. Box 77, postal code 512

Oman

bahaassan@yahoo.com

\section{Biographical notes}

Bahaa-eddin A. Hassan, Ph.D., is an assistant professor in the Department of English at Sohag University, Egypt. He is currently seconded to work as the head of the Department of English at $\mathrm{Al}$ Buraimi University College in Oman. His current research interests lie in linguistics (especially pragmatics) and translation studies.

\section{Publication history}

Date received: 27 April 2018

Date accepted: 27 November 2018

Published online: 27 August 2019 